\title{
A study on problem faced by working women in household activities
}

\author{
SWATI SRIVASTAVA AND R.K. KUSHWAHA
}

Received: 10.12.2014; Accepted: 27.05.2015

See end of the paper for authors' affiliations SWATI SRIVASTAVA

Department of Family Resource Management, Faculty of Home Science, C.S.A.University of Agriculture and Technology, KANPUR (U.P.) INDIA

Email : swati9101990@gamil.com
ABSTRACT : India is a country with divers traditions and custom. In all the religions, women hold a venerable position. Unfortunately, since ages, the role of women was confined to household chores and limited to domestic issues. In the male-dominated Indian society, women suffered to extreme levels of exploitations. The participation of women as workers and women's education was negligible. Indian women's distinct from their western counter parts in that they do not shed their conventional roles as mother and housewives inspire of their professional responsibilities. Thus the present study attempts to study some of the important issues concerns working women, her dual role conditions of work, problem of adjustment between work/domestic duties.

KEY WORDS: Working women, Problem, Household activity

- HOW TO CITE THIS PAPER : Srivastava, Swati and Kushwaha, R.K. (2015). A study on problem faced by working women in household activities. Asian J. Home Sci., 10 (1) : 272-274. 